\title{
ANALYSIS OF THE EFFECT OF TRUST, PRIVACY, AND EFFICIENCY ON E-SATISFACTION IN FORMING E-LOYALTY IN TOKOPEDIA CUSTOMERS IN SURABAYA
}

\author{
Wiwiek \\ Widya Mandala Catholic University \\ wiwiek@ukwms.ac.id
}

\section{A R T I C L E I N F O \\ Article history: \\ Received : 4 April 2020 \\ Revised : 19 April 2020 \\ Accepted : 10 May 2020 \\ JEL Classification:}

Key words:

Trust, Privacy, Efficiency, ESatisfaction, and E-Loyalty.

DOI:

https://doi.org/10.33508/rima.v3i1.2744

\begin{abstract}
A B S T R A C T
This study aims to analyze the effect of Trust, Privacy dan Efficiency; and lastly, the effect of Customer Satisfaction on loyalty consumer of Tokopedia in Surabaya. The sample used in this study are Tokopedia consumer, domicile in Surabaya, having the Tokopedia application, knowing Tokopedia's privacy information, making repeated purchases on Tokopedia in the past 1 (one) year. This study used 165 respondents and SPSS 22.0 to process the data. This model was developed in order to conduct research on E-Loyalty conducted on the online shopping site Tokopedia in Surabaya. This research model is formed from the relationship between Trust, Privacy, Efficiency and E-Satisfaction. Based on the data processing that has been done, it is found that Trust and Privacy have a positive and significant influence on E-Satisfaction; E-Satisfaction has a positive and significant effect on E-Loyalty.
\end{abstract}

\section{INTRODUCTION}

With the development of internet technology that is so fast that business systems have changed from conventional or offline to online, which are all connected in the internet network. The rise of online business has become the forerunner of the birth of electronic-commerce or e-commerce for short, both throughout the world, including in Indonesia. The e-commerce industry has changed the way trade transactions, both retail and wholesaler, are local or global. From year to year, the growth of the e-commerce industry in Indonesia continues to increase. During the 2015-2019 period, e-commerce in Indonesia has increased by up to 500 percent. Based on Google research and the e-Conomy SEA 2018 report, it shows that Indonesia's digital economy in 2019 has reached US \$ 27 billion or around IDR 391 trillion. This means that Indonesia's digital economy transactions have contributed $49 \%$, making Indonesia ranked first for the Southeast Asian region. This is one of the things that must be considered by the government in encouraging the growth of e-commerce in Indonesia. (www.wartaekonomi.co.id, downloaded on February 2, 2020).

The existence of e-commerce in Indonesia increasingly encourages consumptive behavior. With the ease of transacting and choosing products in ecommerce, this has boosted the number of online customers, which is projected to increase by around 25\% each year and will reach 65 million people. In research conducted by McKinsey it shows that 30\% of online shopping is not a routine necessity but an additional value of approximately 42 trillion rupiah in 2017. Online business is predicted to expand to various regions in Indonesia so that the proportion of online shopping is also predicted to increase in value around Rp. seven times in 2022 
(www.wartaekonomi.co.id, downloaded on February 2, 2020).

The online discount portal CupoNation Indonesia released a study on the online shopping site most visited by Indonesians throughout 2019. The study was carried out in the midst of competition for various e-commerce platforms in Indonesia in various ways to become the user's first choice. Quoting data from CupoNation Indonesia, domestic ecommerce platforms still control the number of website visitors throughout 2019 even though several international online shopping sites are also included in the ranks of the e-commerce market in Indonesia. Data states that Tokopedia is the online store most visited by Indonesians with total visitors reaching 1.2 billion, with details of 863.1 million visitors from the mobile web and 329.8 million visitors from the desktop. The second rank is dominated by online shopping site Shopee with a number of visits reaching 837.1 million. This number automatically shifts Bukalapak's position, which in 2019 was visited by 823.5 million visitors. In fourth position onwards is occupied by Lazada with 445.5 million visitors; Blibli with 353.2 million visitors; JD ID with 105.4 million visitors. (www.cnnindonesia.com, downloaded on January 25, 2020).

In its journey, Tokopedia itself must strengthen its positive influence on the Indonesian market share. The Show In 2018, with new funding of US \$ 1.1 billion or equivalent to Rp. 15.95 trillion (exchange rate of Rp. 14,500). This investment was made by the SoftBank Vision Fund and Alibaba Group, as well as previous investors. Tokopedia plans to use the funds to encourage technology and infrastructure development within the company. This benefit of capital will also expand the scale and reach while increasing operational efficiency for millions of businesses and partners in the corporate ecosystem.
Tokopedia itself has provided access to more than 100 million products to people in Indonesia. With the rate of internet usage growing rapidly, Tokopedia will continue to focus on the market in Indonesia to encourage economic development and financial inclusion in Indonesia. Currently, Tokopedia has reached $93 \%$ of sub-districts throughout Indonesia and more than 17,000 islands, so that in 2018 the company's gross merchandise value (GMV) increased by four times (finance.detik.com, downloaded on 7 February 2020).

In Indonesia, the concept of the Tokopedia application is made according to the needs and desires of the Indonesian people. For example, the customer filtering feature makes it easier to find the desired item. Tokopedia customers can also get the ease and completeness of information in ordering orders, such as detailed information on item checkout, shipping methods, use of payment methods and so on. If customers need help, Tokopedia also provides Live Chat features, email, and phone numbers that can be contacted. In addition, Tokopedia also collaborates with many overseas merchants and many official brands that can make it easier for users to find goods that match customer desires. Tokopedia also provides accurate information such as order status information whether the goods ordered by the customer are still packaged, have been shipped, or have arrived at the customer's hands. Information related to merchants on Tokopedia is also provided complete and accurate, for example the speed in responding to customers, the merchant category, and others. Completeness of information on product characteristics and product appearance is also necessary so that customers can be interested and easy to sort products.

Eid (2011), E-Satisfaction is defined as the extent to which customer expectations are met through a comparison 
of the actual performance of the product / service with their initial expectations of performance; where in this research on application / site performance. E-loyalty according to Cyr (2008) is a commitment to consistently revisiting the site because of a preference to shop on that site without switching to another site. Based on this definition, customers are said to be loyal if they visit an online site or use a service on the site repeatedly without switching or moving to other online sites. The point is that the customer does not only visit the online site once or in other words, the customer stops on the first visit, but the customer continues to make repeated and consistent visits for a long time.

An important key to getting loyal customers is to build customer satisfaction based on customer trust in Tokopedia. A study by Mayer et al. (1995) define trust as an expression to accept the opponent's trust (Kim and Park, 2012). In addition, Doney and Cannon stated that trust is one's belief in another person (Kim and Park, 2012). According to Parasuraman et al., (2005), trust is a belief that is felt by customers in relation to a site, product or service, and the information provided is clear and correct. Trust is included in influencing customers' willingness to disclose personal information to make purchases online. McKnight and Chervany (2001), customer trust in ecommerce is when customers believe that the technology used is reliable and credible. Tokopedia has information regarding policies such as privacy policies, refunds and goods, advertising, and others. In addition, information about merchants, order status, and promo information on the Tokopedia application is accurate and complete. Trust is one party's belief regarding the other party's intentions. Thus, trust is emphasized as the main factor determining customer loyalty from many literatures (D'Ambra and Xiao, 2010). Building customer trust in e-commerce will be more difficult because this kind of business model may not provide a physical store that customers can touch and feel directly.

The second factor that also plays an important role, which concerns customers about the data they provide to commerce sites is about customer data privacy. According to Kassim and Abdullah (2010) Privacy refers to the protection of various types of data collected (with or without the user's knowledge) during user interaction with online systems which can also affect the system to be used. Therefore, service providers have felt concern and insecure feelings from service users regarding the possibility of leaking personal data information to others. This presents a unique challenge to the growth and development of online services, especially Tokopedia itself.

The third factor, Efficiency, is the effort to speed and ease in accessing sites which are very important in e-commerce, because the convenience and time savings in accessing a system are generally considered the main reasons for shopping online (Ranganathan \& Ganapathy, 2002). Efficiency refers to when a customer finds the desired product and information on a site with minimal effort (Zeithaml et al. 2002). Whether the site is easy to use, wellstructured, and requires minimum information for customers to search for, it will create a better and more efficient relationship with customers (Parasuraman et al. 2005). Tokopedia provides a Filtering feature so that customers can make it easier to find the specific item they want, for example in terms of product category, type of seller, location, brand, delivery, payment options, appraisal, promotional programs, and price range. Tokopedia provides a "category menu" that makes it easier for customers to find items they need, such as for sale, cheap electronics, shopee fashion, and others. In addition, Tokopedia also 
provides a "sort menu" which can make it easier for customers to choose products.

\section{LITERATURE REVIEW}

1 The Effect of Trust on E-Satisfaction

Research conducted by Lee and Lin (2005) explains that trust in online stores has a positive and significant effect on Customer Satisfaction. In addition, according to Gefen (2000), Trust is the main driver of Customer Satisfaction. Research conducted by Yoon (2002) shows that trust has a positive and significant effect on satisfaction on a website. Kimery and McCord (2002) define trust in e-commerce is when customers are willing to accept sensitivity in online transactions based on positive expectations about future actions. Lim et al. (2001) In an e-commerce environment, trust is defined as the willingness of customers to position themselves in the possibility of losses experienced when shopping transactions via the internet, based on the expectation that the seller promises transactions that will satisfy customers and is able to carry out good quality service to customers. Piercy (2013) Trust is a feeling of security in transactions with companies. Trust is an important determinant of the success of an e-commerce website because it is given that customers and websites are separate from time and place and that products can only be known virtually (Friedrich et al. 2019).

Based on the explanation of theory and previous research, the following hypothesis can be drawn:

Hypothesis 1: Trust has a significant effect on E-Satisfaction

\section{Effect of Privacy on E-Satisfaction}

Ribbink et al. (2004) found that in an online environment, privacy has a high impact on the trust of customers and users even in building long-term relationships with these customers (Al Dmour et al. 2014). Chung and Shin (2010) said that the privacy aspect of data security is very important in increasing satisfaction. This is supported by Jin and Park (2006) in their empirical research which shows privacy has a positive effect on satisfaction. In line with the previous one, Kinasih (2012) also stated that data security privacy has a positive effect on online customer satisfaction. At a certain stage of the transaction, Privacy can affect Trust. So it should be to increase customer satisfaction, e-commerce systems must be able to design secure data security mechanisms (Liu et al., 2008). Privacy in ecommerce is a willingness to share data information online that allows purchases (Armesh et al, 2010). Privacy refers to customer perceptions regarding the possibility of the seller to protect and safeguard customer confidential information during electronic transactions (Kim et al., 2008). Privacy can also be interpreted as an assessment and customer confidence in shopping sites in online stores in storing, safeguarding, and protecting all personal data and information from customers properly and safely (Parasuraman et al. 2005). Zeithaml et al. (2013) Privacy in the form of guarantees from the e-commerce company will be the confidentiality of data from customer behavior during shopping activities on the application or website and also credit / debit card information that is safe and not leaked to outside parties.

Based on the explanation of theory and previous research, the following hypothesis can be drawn:

Hypothesis 2: Privacy has a significant effect on Satisfaction

\section{Effect of Efficiency on E-Satisfaction}

(Kim and Kim, 2010; Waite and Harrison, 2002) found that Efficiency significantly affects Satisfaction. Cai and Xu (2006) stated that an efficient application and website system that can increase the speed of order service processing results in 
higher satisfaction with online retailers. According to Parasuraman et al. (2005) Efficiency is a measure of the ease of a site, where the site is well structured and only requires a minimum of information to use it. In other words, because a website functions as an information system, organization and structure of the online catalog, it must be easy to follow and navigate. Website content must be concise and easy to understand, including all terms and conditions relating to products and services must be easy to read and understand. Türk et al. (2012), Efficiency is the ease and speed of interacting with websites. Zeithaml et al. (2002) defines Efficiency as the ability of customers to enter a website and find the products and information they want, as well as check with minimal effort. Efficiency is the ease and speed of accessing and using a website (Ghosh, 2018). Efficiency can be defined as ease of use related to URL addresses that are easy to remember, catalogs that are well organized, well structured and easy to follow, site navigation capabilities, as well as content, terms and conditions that are concise and easy to understand (Santos, 2003). The existence of an effect of Efficiency on Satisfaction indicates that a system that is very efficient in the use of features by a well-designed customer can reduce the time and cost required to search for customer information which can lead to a higher level of electronic user satisfaction (Kim et al. 2009). The easier efficiency level for customers in finding the products they want and need will also increase customer satisfaction (Wibhawani 2012). Haq et al (2019) stated that Efficiency has a positive and significant effect on customer satisfaction, in which the use of easy and fast applications will increase their satisfaction.

Based on the explanation of theory and previous research, the following hypothesis can be drawn:
Hypothesis 3: Efficiency has a significant effect on Satisfaction

\section{The effect of E-Satisfaction on E-Loyalty}

E-Satisfaction itself has several definitions, including McKinney et al. (2002) define E-Satisfaction as an affective state that represents an emotional reaction to the overall experience of searching on a commerce site. Szymanski and Hise (2000) define E-satisfaction as a result of customer perceptions of convenience, merchandising, site design, and financial security on a website. According to Kim et al. (2009), ESatisfaction is a cumulative construct based on the amount of customer satisfaction on each purchase and consumption experience with goods or services over time. Kotler (2008) states that Satisfaction is an emotional attitude of pleasure or disappointment from customers that comes after comparing perceptions or impressions of the performance or results of a product and its expectations.

E-Loyalty is defined as a customer's intention to buy from a website and a customer's commitment not to change to another website (Flavia'n et al., 2006, Cyr et al., 2005, Azizi and Wang, 2018). E-Loyalty is defined (Srinivasan et al. 2002) as customer attitudes and commitments that can benefit e-retailers which result in repeat buying behavior. It is said to be profitable because loyal customers are more likely to spread positive word of mouth, buy additional services and receive premium prices (Gummerus et al. 2004). According to Liaw (2013) Loyalty in the scope of online business is defined as the behavior of customers, namely repeated visits, using or consuming, and recommending the same website or application. Al-Hawari (2014), Loyalty as a behavior which repurchases on a website or a system that is available based on a certain time period driven by the desire to achieve profits, including aspects of attitude and behavior. The same thing 
was expressed by $\mathrm{Lu}$ et al. (2013), in the world of online business, Loyalty is a very important matter and issue because customers here can easily compare the same services, goods and services in other online businesses.

The positive effect of E-Satisfaction on E-Loyallty has been suggested by several studies (Anderson \& Srinivasan, 2003; Flavián et al. 2006; Harris \& Goode, 2004; Yang \& Peterson, 2004). When customers are satisfied with the website, they will be more willing to interact with the website in the future and generate loyal customers (Anderson \& Srinivasan, 2003; Fang et al. 2011). Satisfied customers will prefer to use the same website (Chou et al. 2015). According to Caruana (2002), overall satisfaction with the perceived experience will lead to customer loyalty. Bearden and Teel (1983) argue that customer satisfaction is a significant determinant of repeat purchases, informing others of the strengths of the website, and customer loyalty. This is also reaffirmed in research Szymanski and Hise (2000) have conducted research so that it is revealed that online satisfaction is widely regarded as an important prerequisite for achieving loyalty. Samuel and Foedjiawati (2005) say that if a customer gets satisfaction from a purchase transaction for a product, this action will build a positive attitude towards the brand itself so that the customer will make purchases consistently. There is a positive relationship between Satisfaction and Loyalty (Keisidou et al 2013). In this study, it shows that the existence of a satisfying experience that a customer gets when making a purchase transaction will cause the customer to return to making purchases on the e-commerce at another time and then become loyal customers (Molden 2014).

Based on the explanation of theory and previous research, the following hypothesis can be drawn:
Hypothesis 4: E-Satisfaction has a significant effect on E-Loyalty

\section{METHODOLOGY}

This study adopts a questionnaire survey method to understand the factors that influence e-loyalty to Tokopedia's customers in Surabaya. Based on the theoretical model of efficiency, then and privacy, it proposes a model of customer satisfaction tokopedia to determine the level of customer loyalty. A total of 165 valid questionnaires were received in this survey. The sample to be selected and taken is based on several criteria determined by the researchers in this study, the characteristics of the sample used are users of the Tokopedia site in Surabaya. The sample used in this study must meet the following criteria: residing in Surabaya, having the Tokopedia application, knowing Tokopedia's privacy information, making repeat purchases on Tokopedia in the last 1 (one) year. Questionnaires were distributed in writing to customers of the Tokopedia site in Surabaya. After the respondent has filled out the questionnaire, only the data from the questionnaire that really meets the sample characteristics criteria will be taken for further processing. To answer each statement in the questionnaire, a Likert scale will be used from a scale of 1 to 5, where each scale represents the answer to strongly disagree to strongly agree.

Before data processing is carried out, it will first be tested for validity and reliability. Validity is the accuracy or accuracy of an instrument in measuring something that you want to measure. The validity test is often used to measure the accuracy of an item in a questionnaire or a related scale whether the item on the questionnaire is appropriate to measure what you want to measure. The testing technique used in testing the validity is Bivariate Pearson Product Moment Correlation. According to Wijaya (2009), if r 
statistic $>\mathrm{r}$ table then the instrument can be declared valid. Reliability test is a study related to the degree of consistency between various measurements of a variable. Cronbach's Alpha is the method most often used to measure the reliability value of data that has been collected. According to Wijaya (2009), if the alpha coefficient is $>0.6$, the instrument can be declared reliable.

Regression analysis is a statistical technique used to analyze the effect of one or more independent variables on one dependent variable. The objective of multiple regression analysis is to use the known value of the independent variable to predict the value of the dependent variable. According to Hair et al. (2006), each independent variable is weighted by a regression analysis procedure to ensure the maximum prediction of a set of independent variables. Referring to the research model used, based on regression analysis, the following equation will be generated:

$\mathrm{ES}=\mathrm{b} 1 \cdot \mathrm{T}+\mathrm{b} 2 \cdot \mathrm{P}+\mathrm{b} 3 . \mathrm{E}$

$\mathrm{EL}=\mathrm{b} 4 . \mathrm{ES}$

Where:

$\mathrm{T}=$ Trust

$\mathrm{P}=$ Privacy

$\mathrm{E}=$ Efficiency

$\mathrm{ES}=$ E-Satisfaction

$\mathrm{EL}=\mathrm{E}$-Loyalty

\section{RESULT AND DISCUSSION}

$\underline{\text { Data analysis }}$

Of the 200 questionnaires distributed, 165 were returned according to characteristics and could be processed. In this study, the overall validity test was carried out with the number of samples (n) $=165$ and $a=0.05(5 \%)$ in order to obtain $r$ table $(n=150)=0.159$. Based on the test, it is known that the rcount value of all indicators is greater than the rtable. Therefore, it can be concluded that all variable indicators in this study are valid.
Based on testing the reliability test results table, it is known that the Cronbach Alpha value of all indicators is greater than 0.6. Therefore, it can be concluded that all variable indicators in this study are reliable.

Based on the Multiple Regression Analysis of Trust (T), Privacy (P), and Efficiency (E) on E-Satisfaction (ES), the R number is 0.527 . This explains that there is a strong correlation. The Adjusted R2 figure of 0.264 shows that Trust $(\mathrm{T})$, Privacy $(\mathrm{P})$, and Efficiency (E) are able to explain $26.4 \%$ E-Satisfaction (ES), while the remaining $73.6 \%$ is influenced by other variables that are not included in this research model. The results of the $F$ test show a significance value of 0.000 , this means that the research model is acceptable. Based on table 1, the following regression equation can be generated:

$\mathrm{ES}=0.173 \mathrm{~T}+0.185 \mathrm{P}+0.275 \mathrm{E}$

The coefficient which is positive indicates a unidirectional change between the independent variable and the dependent variable. Meanwhile, the coefficient which is negative shows a change that is not in the direction of the independent variable and the dependent variable. From the results of the $t$ test that has been done, it can be concluded that:

1. Trust (T) has a significant effect on ESatisfaction (ES) being rejected at the sig level. $0.052>$ t sig. 0.05 .

2. Privacy $(P)$ has a significant effect on ESatisfaction (ES) received at the sig level. $0.035<\mathrm{t}$ sig. 0.05 .

3. Efficiency (E) has a significant effect on ESatisfaction (ES) received at the sig level. $0.001<$ t sig. 0.05 .

Based on the simple regression analysis of E-Satisfaction (ES) to E-Loyalty (EL), the $\mathrm{R}$ number is 0.452 . This explains that there is a moderate correlation. The Adjusted R2 figure of 0.205 indicates that E- 
Satisfaction (ES) is able to explain $20.5 \%$ of E-Loyalty (EL), while the remaining $79.5 \%$ is influenced by other variables not included in this research model. The results of the $\mathrm{F}$ test show a significance value of 0.000 , this means that the research model is acceptable. Based on table 2, the regression equation can be generated as follows:

$\mathrm{EL}=0.452 \mathrm{ES}$

The coefficient which is positive indicates a unidirectional change between the independent variable and the dependent variable. Meanwhile, the coefficient which is negative shows a change that is not in the direction of the independent variable and the dependent variable. From the results of the $t$ test that has been done, it can be concluded that:

E-Satisfaction (ES) has a significant effect on E-Loyalty (EL) received at the sig level. $0,000<$ t sig. 0.05 .

\section{Discussion}

Based on the results of multiple regression analysis, it was found that the first hypothesis which reads Trust has a positive effect although not significant on ESatisfaction at $\alpha=5 \%$, but significant at $\alpha=$ $10 \%$. According to Zikmund (in Soegoto, 2013), trust is related to emotional bonding, namely the ability of a person to trust a company or brand that the company or brand can carry out a function according to his expectations, which will be proportional to repurchase interest and loyalty. Trust according to Morgan and Hunt (1994), is a situation that occurs when one party believes that the other party involved in the transaction together with him has reliability and integrity. In this study, the influence of Trust on E-Satisfaction is insignificant, because during the data collection process (May 2020), Tokopedia faced issues related to data security for its customers. Although this issue was successfully resolved by Tokopedia, however, it inevitably affected Tokopedia's customers' perceptions, in this case the respondent, of Tokopedia's Trust variable.

Privacy has a positive and significant effect on E-Satisfaction. Privacy refers to customer perceptions regarding the possibility of the seller to protect and safeguard customer confidential information during electronic transactions (Kim et al., 2008). Furthermore, according to Roca et al. (2009) Privacy deals with consumers' feelings about the possibility that online companies collect and use data about individuals inappropriately. Thus, if a site system is safe and protects consumer information (Santouridis, 2012), consumers will be satisfied with the site. The ability of online stores to control and maintain security for data transactions, as well as security guarantees, is an important part of the trust-building process by reducing consumer concerns about misuse of personal data and data transactions that are easily damaged (Park and Kim, 2006).

Efficiency has a positive and significant effect on E-Satisfaction. In an online transaction, it is the website that acts as the only intermediary medium that facilitates transactions so that the quality of the website will be the basis for the public's judgment regarding whether or not the website is trusted. Zeithaml et al. (2002) stated that website quality is the quality of a site's services provided to its customers. Website quality is the quality of the technical dimensions, content, and appearance of a website that is considered important by users so that it influences user behavior and evaluation of the website (AlQeisi et al., 2014).

Website quality from the point of view of user satisfaction is to evaluate the 
efficiency of the website in several ways, such as navigation, beauty, function, and other things that affect it (Olsina et al., 2006). Efficiecy can be defined as an evaluation given by users regarding how functional the website's features are in meeting their needs and is a reflection of the advantages of the entire website (Chang and Chen, 2008). Customer satisfaction occurs when the needs or expectations (expectations) for the performance of a customer can be met through their interactions with the company (Tjiptono, 2011). Often what the performance expectations of a system are, come from the performance needs of the person himself. When the performance expectations can be met, someone will feel satisfied with the use of the system.

E-Satisfaction (ES) has a positive and significant effect on E-Loyalty (EL). Szymanski and Hise (2000) have conducted research so that it is revealed that online satisfaction is widely regarded as an important prerequisite for achieving loyalty. Chiu et al. (2009) in their research found a positive influence on the role of Satisfaction in using e-commerce websites on Loyalty. Cristobal et al. (2007) said in their research the Satisfaction variable had a positive effect on Loyalty in online activities. Samuel and Foedjiawati (2005) say that if a customer gets satisfaction from a purchase transaction for a product, this action will build a positive attitude towards the brand itself so that the customer will make purchases consistently. There is a positive relationship between Satisfaction and Loyalty (Keisidou et al 2013). Customer satisfaction has a positive effect on loyalty. In this study, it shows that the existence of a satisfying experience that a customer gets when making a purchase transaction will cause the customer to return to make purchases in $\neg$ e-commerce at another time and then become a loyal customer (Molden 2014).

\section{CONCLUSION}

This model was developed in order to conduct research on E-Loyalty conducted on the online shopping site Tokopedia in Surabaya. This research model is formed from the relationship between Trust, Privacy, Efficiency and E-Satisfaction. Based on the data processing that has been done, it is found that Trust and Privacy have a positive and significant influence on ESatisfaction; E-Satisfaction has a positive and significant effect on E-Loyalty.

\section{$\underline{\text { Recommendation }}$}

Looking at the results of existing research where there are still many limitations to the research conducted by the author, further research is expected to complement the existing variables in this study so that it can further enhance understanding of the factors that affect ELoyalty. Further research can expand the coverage of respondents who will be researched or carry out their research in a different area from the research that has been carried out at this time. The goal is that the further research carried out can provide a broader picture of E-Loyalty.

\section{REFERENCES}

Soegoto, A.S., (2013). Persepsi Nilai dan Kepercayaan Terhadap Kepuasan dan Dampaknya Terhadap Loyalitas Konsumen. Jurnal Emba, 1 (3), 1271 1283

Al Dmour, H., Alshurideh, M., \& Shishan, F. (2014). The influence of mobile application quality and attributes on the continuance intention of mobile shopping. Life Science Journal, 11(10), 172-181. 
Al-Hawari, M. A. (2014). Does Customer Sociability Matter? Differences in Equality, E-satisfaction, and E-loyalty Between Introvert and Extravert Online Banking Users. Journal of Services Marketing.

Al-Qeisi, K., Dennis, C., Alamanos, E., \& Jayawardhena, C. (2015). Website design quality and usage behavior: Unified Theory of Acceptance and Use.

Anderson, R., \& Srinivasan, S. (2003). Esatisfaction and E-loyalty: A Contingency Framework. Psychology \& Marketing, 123-128.

Armesh, H., H. Salarzehi, NM. Yaghoobi, A. Heydari \& D. Nikbin. (2010). The Effects of Security and Privacy Information on Trust and Trustworthiness and Loyalty in Online Marketing in Malaysia. International Journal of Marketing Studies, 2 (2), 223-234.

Azizi, F., \& Wang, X. (2018). Your Secret Weapon to Achieve E-Loyalty: A Quantitative Study on Antecedents Leading to E-loyalty. Business Administration.

Bearden, W., \& Teel, J. (1983). Selected Determinants of Consumer Satisfaction and Complaint Reports. Journal of Marketing Research, 21 28.

Cai, S., Xu, Y., (2006). Effects of outcome, process and shopping enjoyment online consumer behavior. Electronic Commerce Research and Applications 5, 272-281.

Caruana, A. (2002). Service Loyalty the Effects of Service Quality and The Mediating Role of Customer satisfaction. European Journal of Marketing, 811-828.

Chang, H. H., \& Chen, W. S. (2008). The Impact of Customer Interface Quality, Satisfaction and Switching Costs On E-loyalty: Internet Experience as A Moderator. Computers in Human Behavior, 2927-2944.

Chou, S., Chen, C.-W., \& Lin, J.-Y., (2015). Female Online Shoppers: Examining The Mediating Roles of E-satisfaction and E-trust On E-loyalty Development. Internet Research, 542561.

Chiu, C. M., Lin, H. Y., Sunc, S. Y., \& Hsu, M. -H., (2009). Understanding customers' loyalty intentions toward online shopping: an integration of technology model and fairness theory. Behaviour \& Information Technology, Vol. 28, No. 4, 347-60.

Chung, K. H.., \& Ji. Shin. (2010). The Antecedents and Consequents of Relationship Quality in Internet Shopping. Asia Pasific Journal of Marketing and Logistics, 22(4), 473491.

Cristobal, E., Flavian, C., Guinaliu, M. (2007). Percieved e-service quality (PeSQ): Measurement validation and effects on consumer satisfaction and website loyalty. Managing Service Quality 17(3), 317-340.

Cyr, D. (2008). Modeling Web Site Design Across Cultures: Relationships to Trust, Satisfaction, and E-Loyalty. Journal of Management Information Systems, 24(4), 47-72.

Cyr, D., Bonanni, C., Bowes, E. J., \& Ilsever, J. (2005). Beyond Trust: Website Design Preferences Across Cultures. 
Journal of Global Information Management.

D'Ambra, J. and L. Xiao, 2010. An Empirical study of multi-dimensional trust and eloyalty in E-commerce in China. Proceedings of the AMCIS, (CIS' 10), pp: 62-62.

Doney, P., \& Cannon, J. (1997). An Examination of the Nature of Trust in Buyer-Seller Relationships. Journal of Marketing, 35-51

Eid, M. I. (2011). Determinants of ecommerce customer satisfaction, trust and loyalty in Saudi Arabia. Journal of Electronic Commerce Research, Vol. 12, No. 1, 78-93

Fandy, Tjiptono. (2011). Service Management Mewujudkan Layanan Prima.Edisi 2. Yogyakarta: Andi.

Fang, Y.- H., Chiu, C.- M., \& Wang, E., (2011). Understanding Customers' Satisfaction and Repurchase Intentions: An Integration of Is Success Model, Trust, And Justice. Internet Research, 479-503.

Flavia'n, C. \& M. Guinali'u. (2006). Customer Trust, Percieved Security and Privacy Policy Three Basics Elements of Loyalty to a Website. Industrial Management \& Data Systems 106(5), 601-620.

Friedrich, T., Schlauderer, S., \& Overhage, S. (2019). The Impact of Social Commerce Feature Richness On Website Stickiness Through Cognitive and Affective Factors: An Experimental Study. Electronic Commerce Research and Applications.

Gefen, D. (2000). E-commerce: The Role of Familiarity and Trust. The international Journal of Management Science, 725-37.

Ghosh, M. (2018). Measuring Electronic Service Quality in India Using E-squal Instrument. International Journal of Quality \& Reliability Management, 430-445.

Gummerus, J., Liljander, V., Pura, M., \& Riel, A. v. (2004). Customer Loyalty to Content-Based Web Sites: The Case of an Online Health-Care Service. Journal of Services Marketing, 176.

Hair, J.F., Jr. Black, W.C., Babin, B.J., \& Anderson, R.E. (2010). Multivariate Data Analysis (7th ed.). New Jersey: Prentice Hall, Inc. Harris, L. C., \& Goode, M. M. (2004). The four Levels of Loyalty and the Pivotal Role of Trust: A Study of Online Service Dynamics. Journal of Retailing, 80(2), 139-158.

Haq, Faishal, Junaidi, Mujidi Sabar., (2019). The influence of Efficiency, Reliability, and Responsiveness towards Ecustomer satisfaction on Redkendi Appliaction Jakarta. Internal Journal of Innovative Science and Research Technology volume 4, Issue 12.

Jin, B. \& J.Y. Park. (2006). The Moderating Effect of Online Purchase Experience on the Evaluation of Online Store Attributes and the Subsequent Impact on Market Response Outcomes. Advances in Consumer Research, 33, 203-211.

Kassim, N. \& Abdullah, N.A. 2010. The Effect of Perceived Service Quality Dimensions on Customer Satisfaction, Trust, and Loyalty in E-Commerce Settings, Asia Pacific Journal of 
Marketing and Logistics, Vol. 22 No. 3, pp. 351-371.

Keisidou, E., Sarigiannidis, L., Maditinos, D. I. \& Thalassinos, E. I. (2013). Customer Satisfaction, Loyalty, And Financial Performance. International Journal of Bank Marketing, Vol. 31, No. 4, 259288.

Kim, D., D. Ferrin and H. Rao, 2008. A trustbased consumer decision-making model in electronic commerce: The role of trust, perceived risk and their antecedents. Decision Support Syst., 44: 544-564. DOI: 10.1016/j.dss.2007.07.001

Kim, J. and H. Park, 2012. Fast nonnegative tensor factorization with an active-setlike method. High Performance Sci. Comput., Springer London.

Kim, J., Jin, B., \& Swinney, J. L. (2009). The role of etail quality, e-satisfaction and e-trust in online loyalty development process. Journal of Retailing and Consumer Services, 16(4), 239-247.

Kim, J. H., Kim, C., (2010). E-service quality perceptions: a cross-cultural comparison of American and Korean Consumers. Journal of Research in Interactive Marketing, 257-275.

Kimery, K., \& Mccord, M. (2002). Thirdparty Assurances: Mapping The Road to Trust in E-retailing. Journal of Information Technology Theory and Application, 63-82.

Kinasih, B. S. (2012). Pengaruh Persepsi Keamanan dan Privasi terhadap Kepuasan dan Kepercayaan Konsumen Online. Jurnal Manajemen, Vol. 16, No. 1, 25-38.
Kotler, Phillip dan Gary Amstrong. (2008). Prinsip-prinsip Pemasaran, jilid 2, edisi 8. Jakarta: Penerbit Erlangga.

Lee, G.-G., \& Lin, H.-F. (2005). Customer Perceptions of E-service Quality in Online Shopping. International Journal of Retail \& Distribution Management, 161-176.

Liaw, G. F. (2013). The Effects of Trust, Satisfaction, and Switching cost on Customer's Loyalty - A model of online auction. Journal of Internasional Management Studied Vol 8 number 1, 59-67.

Lim, K. H. (2001). "How Do I Trust You Online and If So, Will I buy?". Journal of Management Information System., -

Liu, X., Gao, F., He, M., \& Xie, P. (2008). An Empirical Study of Online Shopping Customer Satisfaction in China: A Holistic Perspective. International Journal of Retail \& Distribution Management, 919-940.

Mayer, R., Davis, J., \& Schoorman, F. D. (1995). An Integrative Model of Organizational Trust. Academy ol Management Review, 709-734.

McKinney, V., Yoon, K., \& Zahedi, F. “. (2002). The Measurement of WebCustomer Satisfaction: An Expectation and Disconfirmation Approach. Information Systems Research, 296315.

Mc-Knight, D., \& Chervany, N. (2001). What Trust Means in E-Commerce Customer Relationships: An Interdisciplinary Conceptual Typology. International Journal of Electronic Commerce, 35-59. 
Molden, Elrado, H., dkk. (2014). Pengaruh Kualitas Pelayanan Terhadap Kepuasan, Kepercayaan, dan Loyalitas (Survei pada Pelanggan yang Menginap di Jambuluwuk Batu Resort Kota Batu). Jurnal Administrasi Bisnis Vol. 15, No. 2, Universitas Brawijaya.

Olsina, Luis. (1999). Website Quality Evaluation Method: a Case Study on Museums. dari https://www.researchgate.net/public ation/238176321_Website_Quality_Ev aluation

Method_a_Case_Study_on_Museums

Parasuraman, A., Zeithaml, V., \& Malhotra, A. (2005). E-S-QUAL: A Multiple-Item Scale for Assessing Electronic Service Quality. Journal of Service Research, 213-233.

Park, Chung-Hoon., \& Young-Gul Kim. (2006). "The Effect of Information Satisfaction and Relational Benefit on Consumer Online Site Commitmennts". Journal of Electronic Commerce in Organizations, 4 (1), 7090.

Piercy, N. (2013). Online Service Quality: Content and Process of Analysis. Journal of Marketing Management, 747-785.

Ranganathan, C \& S. Ganapathy. (2002). Key Dimensions of "Business-ToConsumer" Web Sites. Information and Management, 457-465.

Ribbink, D., Riel, A. v., Liljander, V., \& Streukens, S. (2004). Comfort Your Online Customer: Quality, Trust and Loyalty On the Internet. Managing Service Quality, 446-456.
Roca, JC., JJ. Garcia and JJ. De la Vega. (2009). The Importance of Percieved Trust, Security, And Privacy in Online Trading Systems. Information Management \& Computer Security. 17 (2), 96-111.

Samuel, Hatane dan Foedjiawati. (2003). Pengaruh Kepuasan Konsumen Terhadap Kesetiaan Merk (Studi Kasus Restoran the Prime Steak \& Ribs Surabaya). Jurnal Manajemen dan Kewirausahaan, Vol. 7, Surabaya, UKP.

Santos, J. (2003). E- service Quality: A Model of Virtual Service Quality Dimensions. Managing Service Quality: An International Journal, 233246.

Santouridis, I., Trivellas, P., \& Tsimonis, G. (2012). Using E-S-QUAL to measure internet service quality of e-commerce websites in Greece. International Journal of Quality and Service Sciences 4(1), 86-98.

Srinivasan, S. S., Anderson, R., \& Ponnavolu, K. (2002). Customer Loyalty in e-commerce: an exploration of its antecedents and consequences. Journal of Retailing, 78, 41-502.

Szymanski, D. M. \& Hise, R. T. (2000). eSatisfaction: An Initial Examination. Journal of Retailing 76(3), 309-322.

Türk, B., Scholz, M., \& Berresheim, P. (2012). Measuring Service Quality in Online Luxury Goods Retailing. Journal of Electronic Commerce Research, 88-103.

Waite, K., \& Harrison, T. (2002). Consumer Expectations of Online Information Provided by Bank Web Sites. Journal 
of Financial Services Marketing, 30922.

Wibhawani, G. A. (2012). Pengaruh Kualitas Pelayanan Tiket Elektronik Terhadap Kepuasan Pelanggan Garuda Indonesia.

http://batik.imtelkom.ac.id/pustaka/16203 $\angle$ pengaruhkualitas-pelayanantiketelektronikterhadapkepuasanpelanggan-garudaindonesia-tahun2012.html,

Wijaya, T. (2009). Analisis Data Penelitian Menggunakan SPSS. Yogyakarta.

Yang, Z., \& Peterson, R. (2004). Customer Perceived Value, Satisfaction, And Loyalty: The Role of Switching Costs. Psychology \& Marketing, 799-822

Yoon, S.-J. (2002). The Antecedents and Consequences of Trust in Onlinepurchase Decisions. Journal of Interactive Marketing, 47-63.

Zeithaml, V.A., Bitner, M.J., \& Gremler, D.D. (2013). Services Marketing Integrating Customer Focus Across the Firm. Singapore: McGraw-Hill, Inc. International Edition.

Zeithaml, V., Parasurarnan, A., \& Malhotra, A. (2002). Service Quality Delivery Through Web Sites: A Critical Review of Extant Knowledge. Journal of the Academy of Marketing Science, 362375.

https://www.wartaekonomi.co.id/read163

561/iklan-shopee-sabet-penghargaanbright-awards-indonesia

https://www.cuponation.co.id/magazin/t

oko-online-paling-populer-diindonesia

https://www.cnnindonesia.com/teknologi L20190904193850- https:// finance.detik.com/berita-ekonomibisnis/d-4339772/tokopedia-diguyurrp-16-triliun-oleh-softbank--alibaba https://finance.detik.com/berita-ekonomibisnis/d-4340272/tokopediadidirikan-penjaga-warnet-hinggajadi-perusahaan-rp-101-t 